Sains Malaysiana 49(2)(2020): 283-291

http://dx.doi.org/10.17576/jsm-2020-4902-06

\title{
Effects of Different Preservation Treatments on Nutritional Profile on Juices from Different Sugar Cane Varieties
}

(Kesan Rawatan Pengawetan Berbeza pada Profil Nutrisi Jus daripada Pelbagai Variasi Tebu)

\author{
Nusrah Mansor, Shazini Ramli, Siti Hajar AzHari \& Muhamad Hafiz Abd Rahim*
}

\section{ABSTRACT}

The commercialisation of sugarcane juice is limited due to its rapid quality degradation. This study was conducted to determine the effect of High Pressure Processing (HPP) and High Pressure Homogenisation (HPH) on physicochemical, antioxidant properties and microbiological quality of red sugarcane juice. The red sugarcane juice samples, Kapur, Madu, Serai and Ragnar were subjected to HPP and HPH at 300 MPa for 2 and 5 min before the analysis was performed. Initial brix content, polyphenol oxidase (PPO) and nutritional content of sugarcane juice values of showed that Madu juice contained the highest total phenolic content (TPC) and antioxidant properties (FRAP and DPPH radical scavenging assay) amongst all variants. HPP-treated juice showed no significant difference to the untreated juice in terms of physicochemical properties (total soluble solid, $\mathrm{pH}$ and colour), microbial count and polyphenoloxidase activity. In contrast, HPH showed significant decrease in microbial load and polyphenoloxidase activity. The sugar cane juice subjected to HPP and HPH for 5 min showed significant increase and significant decrease, respectively, in term of TPC as compared to untreated sample. In conclusion, HPP appears to be an effective approach to retain TSS, $p H$ and colour of the red sugarcane juice, while increasing the antioxidant quantity which is desirable in the commercialisation of the juice. However, HPH is a better method to reduce PPO activity and microbial load, thus beneficial in reducing the browning process and potentially extending the shelf life.

Keywords: High pressure homogenization; high pressure processing; red sugarcane juice

ABSTRAK

Pengkomersialan jus tebu adalah terhad kerana kemerosotan kualiti yang cepat. Kajian ini dijalankan bagi menentukan kesan Pemprosesan Tekanan Tinggi (HPP) dan Homogenisasi Tekanan Tinggi (HPH) terhadap sifat fizikokimia, antioksidan dan kualiti mikrobiologi jus tebu merah. Jenis jus tebu merah yang terpilih iaitu Kapur, Madu, Serai dan Ragnar telah dirawat HPP dan HPH pada 300 MPa selama 2 dan 5 min sebelum analisis dilakukan. Analisis kandungan brix awal, polifenol oksida (PPO) dan nilai kandungan nutrisi jus tebu menunjukkan bahawa jus Madu mengandungi jumlah kandungan fenolik tertinggi (TPC) dan sifat antioksidan tertinggi (asai FRAP dan asai perencatan radikal DPPH) dalam kalangan semua varians. Jus yang dirawat HPP tidak menunjukkan perbezaan yang ketara terhadap jus yang tidak dirawat daripada segi sifat fizikokimia (jumlah larut pepejal, pH dan warna), kiraan mikrob dan aktiviti polifenol oksidase. Sebaliknya, HPH menunjukkan penurunan ketara dalam aktiviti mikrob dan aktiviti polifenol oksidase. Jus tebu yang dirawat HPP dan HPH selama 5 minit masing-masing menunjukkan peningkatan dan penurunan yang ketara daripada segi TPC berbanding sampel yang tidak dirawat. Kesimpulannya, HPP dilihat berkesan untuk mengekalkan TSS, $p H$ dan warna jus tebu merah, sambil meningkatkan kuantiti antioksidan yang diinginkan dalam mengkomersialkan jus. Walau bagaimanapun, HPH adalah kaedah yang lebih baik untuk mengurangkan aktiviti PPO dan beban mikrob, dengan itu memberi manfaat dalam mengurangkan proses pemerangan dan berpotensi memanjangkan jangka hayat.

Kata kunci: Homogenisasi tekanan tinggi; jus tebu merah; pemprosesan tekanan tinggi

\section{INTRODUCTION}

Sugarcane is an important agricultural commodity in term of table sugar (crystalline sucrose) production. Due to its sweet taste and its excellent aroma, sugarcane juice is also consumed around the world especially in the tropical countries. Although sugarcane juice is rich in sugar, this drink also contains good nutrients including vitamins, amino acids, minerals and antioxidants (Kadam et al. 2008). Sugarcane is often classified based on its skin colour, although the colour does not necessarily present in the juice. In Malaysia, yellow sugarcane juice is often utilised for juice production due to certain favourable characteristics such as soft stalk, high juice content and less fibrous (Qudsieh \& Yassin 2001). However, there are also other lesser known variants that possess excellent sensory properties. They are not utilised as much as yellow sugarcane due to lesser juice production and harder stalk, which complicates the process of extracting the juice.

As the juice is high in sugar and water activity, it is prone to enzymatic and microbial quality degradation. 
According to Yusof et al. (2000), without a proper storage for freshly extracted juice, it can barely last a day under room temperature, while chilling at $4^{\circ} \mathrm{C}$ can extend its shelf life up to 5 days. The degradation of qualities, which is unfit for consumption, is marked by unpleasant smell, acid formation, increased in viscosity and change in colour. These changes are contributed by the microbial growth due to unhygienic extraction procedure, action of polyphenol oxidase (PPO) and sucrose destruction reaction that accelerate the enzymatic degradation and microbial growth that influence the $\mathrm{pH}$ and viscosity (Qudsieh \& Yassin 2001).

The commercialisation of this juice often involves the use of heat to reduce the number of microbial load and inactivate the enzymes that contributed to the spoilage. However, the use of heat may cause some undesirable alteration to the physicochemical and nutritional characteristics of the sugarcane juice. For example, heat was shown to reduce the clarity, total soluble solid and antioxidant properties of the juice (Hajar et al. 2018). Compared with the thermal processing, the non-thermal treatment can preserve their nutritional content as well as taste of the fresh juice. For example, ultrasound has been tested on sugarcane juice and successfully retained most of the physicochemical characteristic of the juice, although its effectiveness in reducing the microbial load is inferior to the heat treatment (Hajar et al. 2018). Meanwhile, high pressure processing (HPP), which utilises short-duration heavy pressure, was shown to be more effective in reducing the microbial growth and deactivating spoilage enzyme in certain fruit juices (Huang et al. 2015). High pressure homogeniser (HPH) also demonstrated excellent preservation results in fruit juice (Bevilacqua et al. 2010). Other factors that can contribute to the efficiency of the processing such as pressure, temperature, numbers of passes and medium factors such as variety of juice and microbes (Vasantha Rupasinghe \& Yu 2012).

Given that sugarcane comprises many subspecies, different type of sugarcane juices that exhibit different characteristics were used in this study. The major determinants for the sugarcane juices in this study were their Brix content and PPO value. Four local subspecies of red sugarcane juices were selected; Ragnar, Madu (honey), Kapur (chalk) and Serai (lemongrass). This current study will investigate the effect of HPP and HPH on the preservation of different sugarcane juices in term of its changes in the quality profiles. The data from this study would provide an insight on how to treat different type of sugarcane juice for commercialisation when using the non-thermal technology of HPP and HPH.

\section{MATERIALS AND METHODS}

\section{CHEMICALS}

Hydrochloric acid, glacial acetic acid, sodium acetate (anhydrous), ferric chloride, methanol, sodium carbonate, gallic acid, peptone from meat were supplied by Merck
(Darmstadt, Germany). Folin-Ciocalteu reagent, 1,1-diphenyl-2-picrylhydrazyl (DPPH) free radical powder, ferrous sulfate heptahydrate $\left(\mathrm{FeSO}_{4} \cdot 7 \mathrm{H}_{2} \mathrm{O}\right), 4,6$-tripryridylstriazine (TPTZ), disodium phosphate and monosodium phosphate were supplied by Sigma (Aldrich, Germany). Plate count agar was supplied from Oxoid (Basingstoke, England). Catechol was supplied by Fisher Scientific (Norcross, GA).

\section{MATERIALS}

Red and yellow sugarcane juice varieties, namely Kapur, Madu, Serai and Ragnar were obtained from a sugarcane farm located at Sungai Petani, Kedah. The red sugarcanes were freshly harvested when reached its maturity stage. The middle parts of the red sugarcanes were cut, cleaned and crushed using power roller to obtain the juice. The samples were immediately stored at $-20^{\circ} \mathrm{C}$ to prevent any spoilage.

\section{HIGH PRESSURE PROCESSING TREATMENT OF RED SUGARCANE JUICE}

Each of varieties of red sugarcane juice sample was packed into two plastic bottles. The plastic bottles were sterilized using UV light for $30 \mathrm{~min}$ before used. Each of plastic bottles filled with the volume of $60 \mathrm{~mL}$ of sample. Next, the bottles were placed in a cylindrical loading container and pressurized at $300 \mathrm{MPa}$ for $2 \mathrm{~min}$ and $5 \mathrm{~min}$, respectively at $24.7^{\circ} \mathrm{C}$ using High Pressure Processing machine (Model QFP 2L-700 Laboratory Food Processing System, Avure Technologies, USA) at Agro-Biotechnology Institute Malaysia. Deionized water was used to transmit pressure.

\section{HIGH PRESSURE HOMOGENISATION TREATMENT OF RED SUGARCANE JUICE}

HPH experiments were carried out using laboratory scale high pressure homogenizer system in bacterial fermentation lab of Institute of Bioscience (IBS). The red sugarcane juice samples subjected to High Pressure Homogenizer (Model EmulsiFlex-C50, Avestin Inc., Ottawa, Canada) at 300 $\mathrm{MPa}$ for $2 \mathrm{~min}$ and $5 \mathrm{~min}$, respectively.

\section{PH ANALYSIS}

The $\mathrm{pH}$ of the sample was determined using a $\mathrm{pH}$ meter. The $\mathrm{pH}$ meter was first calibrated using standard buffer solutions at $\mathrm{pH} 4$ and 7 . The $\mathrm{pH}$ test strip was dipped into the sample. The tests for each sample were conducted in triplicate and the average of all values taken.

\section{DETERMINATION OF PH, TOTAL SOLUBLE SOLID (TSS) AND COLOUR MEASUREMENT}

TSS was measured by portable refractometer (Model N1, ATAGO CO., LTD., Tokyo, Japan, ${ }^{\circ}$ Brix 0-32\%) and expressed in terms of Brix degrees ( ${ }^{\circ}$ Brix). pH was determined using $\mathrm{pH}$ meter (Mettler Toledo, Schwerzenbach, 
Switzerland). The colour measurements were performed using a Hunter Lab Calorimeter Ultra-Scan, Model SN 7877.

\section{ANTIOXIDANT ASSAYS}

A modified 96-well microplate Folin-Cioalteu assay was used for estimating total phenolic content (TPC) in red sugarcane juice. 10\% Folin-Ciocalteu reagent (FCR) was prepared by mixing $1 \mathrm{~mL}$ of the FCR with $9 \mathrm{~mL}$ of distilled water. $20 \mu \mathrm{L}$ of ten-fold diluted samples were transferred to the wells of 96-well. Next, $100 \mu \mathrm{L}$ of FCR was added and mixed well. Then, the mixtures were left standing at room temperature for $5 \mathrm{~min}$. $80 \mu \mathrm{L}$ of $7.5 \%$ sodium carbonate solution was added after $5 \mathrm{~min}$ and left in dark condition for $30 \mathrm{~min}$. The absorbance was read using BIORAD 170-6930 Benchmark Plus Microplate Spectrophotometer at $750 \mathrm{~nm}$.

FRAP assay was performed according to Benzie and Strain (1999) with slight modification. FRAP reagent was freshly prepared and heated to $37^{\circ} \mathrm{C}$ in water bath. $20 \mu \mathrm{L}$ of ten-fold diluted sample added to the well of 96-well microplate followed by $180 \mu \mathrm{L}$ of working FRAP reagent. The absorbance of reaction mixture was measured using BIO-RAD 170-6930 Benchmark Plus Microplate Spectrophotometer at $593 \mathrm{~nm}$ after incubation at $37^{\circ} \mathrm{C}$ for $4 \mathrm{~min}$.

DPPH (1, 1-diphenyl-2-picrylhydrazyl) assay was performed as described by Takara et al. (2007) with some modifications. $50 \mu \mathrm{L}$ of ten-fold diluted sample was transferred into the 96 well microplates followed by addition of $100 \mu \mathrm{L}$ of DPPH reagent. The mixture was mixed well and covered with aluminum foil for $30 \mathrm{~min}$ at room temperature. The absorbance of reaction mixture was read using BIO-RAD 170-6930 Benchmark Plus Microplate Spectrophotometer at $517 \mathrm{~nm}$.

\section{POLYPHENOLOXIDASE (PPO) ACTIVITY ASSAY}

Assay of PPO activity was carried out according to Siguemoto and GUT (2017) with slight modification. 100 $\mu \mathrm{L}$ of $0.1 \mathrm{M}$ sodium phosphate buffer ( $\mathrm{pH} 6.5$ ) was added to the 96 -well microplate followed by $33 \mu \mathrm{L}$ of the ten-fold diluted juice. The reaction was initiated by addition of $67 \mu \mathrm{L}$ of $0.1 \mathrm{M}$ catechol and incubated for $30 \mathrm{~min}$ at room temperature. The absorbance of reaction mixture was read using BIO-RAD 170-6930 Benchmark Plus Microplate Spectrophotometerat $420 \mathrm{~nm}$.

\section{TOTAL PLATE COUNT}

Plate count agar (PCA) was prepared according to manufacturer's instruction. $1 \mathrm{~mL}$ of sample was transferred into a universal bottle containing $9 \mathrm{~mL}$ of $0.1 \%$ buffered peptone water $\left(10^{-1}\right.$ dilution). The mixture was homogenized using vortex and serial dilution was done up to $10^{-4}$. Next, $0.1 \mathrm{~mL}$ from $10^{-3}$ and $10^{-4}$ dilution were pipetted and spread on PCA agar for viable count using sterile glass rod. The plates were inverted and incubated at $37^{\circ} \mathrm{C}$ for $48 \mathrm{~h}$. The microbiological analysis would include total counts on bacteria, yeast and mold as well as the coliforms count
(Yusof et al. 2007). The total counts on bacteria, yeast and mould will be expressed as colony forming unit (CFU) per millilitre.

\section{STATISTICAL ANALYSIS}

All the data were reported as in the form of graphic image of triplicate measurements except total plate count. Oneway analysis of variance (ANOVA) and Tukey's test were performed to detect differences among the juices for each parameter considered using Minitab 16 (Minitab Inc. State College, Pa. U.S.A).

\section{RESULTS AND DISCUSSION}

Sugarcane juice is known to possess high sugar content, coupled with appreciable nutritional qualities. Initial brix content, PPO and nutritional content of sugarcane juice values of different sugarcane juices are shown in Table 1. Kapur and Serai were significantly lower in TSS compared to Madu and Ragnar variant. The higher amount of Brix (in form of sugar) might increase the likelihood of microbial contamination by microorganism, as microorganism requires carbon source for its growth. However, if the concentration of sugar is high enough, such as honey, it will prevent the growth of microorganism instead as the water activity is too low of them to thrive. In this case, the difference in TSS and sugar content of different sugarcane juices did not influence the initial microbial growth, as demonstrated by the insignificant differences of microbial count in different sugarcane juices. Therefore, in order to preserve the juice for commercialisation purpose, similar approach can be undertaken for different variants of sugarcane as different TSS and sugar content are shown not to be the factor for microbial growth.

However, different sugarcane variants possessed significantly different PPO content, except for Ragnar and Serai variant. Kapur possessed the highest PPO content whilst Madu is the lowest. This is also evident in the juice itself as Kapur exhibited dark grey colour while Ragnar and Serai exhibited dark green colour while Madu exhibited light green colour. In term of nutritional content, Madu consistently showed higher antioxidant properties, as demonstrated by its TPC, $\mathrm{EC}_{50}$ and FRAP. Meanwhile, Ragnar and Serai showed significantly lower antioxidant potential. Overall, these results indicated that Ragnar and Serai are closely related in term of its nutritional and PPO content, although their Brix are significantly different from each other. In term of commercialization setting, Ragnar is the most preferred variety due to its sweet taste and highly aromatic smell.

\section{THE EFFECT OF HPP AND HPH TREATMENTS ON COLOUR QUALITY OF SUGARCANE JUICES}

Colour is an important trait, as it may improve the customers' preference towards the food product. Colour 
coordinates $\mathrm{L}^{*}$ is related to the total amount of light passing, $a^{*}$ and $b^{*}$ for the green-red and blue-yellow colour components respectively. Table 2 demonstrates the effects of HPP and HPH on colour measurement of the different variants of red sugarcane juice.

Sugarcane contains many pigment or colorant compounds includes chlorophylls, xanthophylls, carotene, and anthocyanins (Chen \& Chou 1993). Madu showed the highest in $L^{*}$ and $b^{*}$ values among variants before and after all treatments. This indicates that juice colour of Madu juice is the lightest and the most yellow in colour among other variants. In contrast, Kapur showed the highest a* value before and after all the treatments, which indicated darker appearance of the juice. This observation is in line with the naked eye observation and the amount of initial PPO, as mentioned in the earlier paragraph.

Results showed that HPP treatment had no significant effect $(p>0.05)$ on the values of $L^{*}$ and $a^{*}$ compared to untreated sample at all-time points. Similar results done by Zhou et al. (2014), who reported that they did not found any significant changes in the $\mathrm{L}^{*}, \mathrm{a}^{*}$ and $\mathrm{b}^{*}$ values of HPP-treated pumpkin. Sreedevi and Kameswari (2017) also found a little effect on colour in sugarcane juice after $\mathrm{HPP}$ at $300 \mathrm{MPa}$ and $400 \mathrm{MPa}$ for $10 \mathrm{~min}$. Although some

TABLE 1. Initial brix content, PPO and nutritional content of sugarcane juice

\begin{tabular}{lcccccc}
\hline Juice varieties & Brix & PPO & TPC & EC50 & FRAP & Plate count \\
\hline Kapur & $11.40 \pm 0.20^{\mathrm{B}}$ & $2.77 \pm 0.1^{\mathrm{A}}$ & $390.21 \pm 0.03^{\mathrm{AB}}$ & $50.44 \pm 1.41^{\mathrm{B}}$ & $3.05 \pm 0.03^{\mathrm{AB}}$ & $6.32 \pm 0.35^{\mathrm{A}}$ \\
Madu & $13.73 \pm 0.46^{\mathrm{A}}$ & $0.77 \pm 0.06^{\mathrm{C}}$ & $421.05 \pm 0.27^{\mathrm{A}}$ & $36.98 \pm 2.69^{\mathrm{C}}$ & $3.16 \pm 0.27^{\mathrm{A}}$ & $6.47 \pm 0.18^{\mathrm{A}}$ \\
Serai & $11.73 \pm 0.31^{\mathrm{B}}$ & $0.91 \pm 0.05^{\mathrm{BC}}$ & $328.96 \pm 0.09^{\mathrm{B}}$ & $60.89 \pm 5.39^{\mathrm{A}}$ & $2.66 \pm 0.09^{\mathrm{B}}$ & $6.34 \pm 0.36^{\mathrm{A}}$ \\
Ragnar & $14.33 \pm 0.12^{\mathrm{A}}$ & $0.97 \pm 0.03^{\mathrm{B}}$ & $358.13 \pm 0.2^{\mathrm{AB}}$ & $55.66 \pm 1.85^{\mathrm{AB}}$ & $2.76 \pm 0.21^{\mathrm{AB}}$ & $6.30 \pm 0.36^{\mathrm{A}}$ \\
\hline
\end{tabular}

*Each value from the table represents mean \pm standard deviation $(n=3)$. Values with superscript letters represent significant difference (Tukey's test, $\mathrm{p}<0.05$ ) between red sugarcane varieties within the same column

TABLE 2. The effect of preservation treatments on the colour change of different sugarcane juice variants

\begin{tabular}{|c|c|c|c|c|c|}
\hline \multirow[t]{2}{*}{ Varieties } & \multirow[t]{2}{*}{ Treatment } & \multicolumn{4}{|c|}{ Colour value } \\
\hline & & $\mathrm{L}^{*}$ & $a^{*}$ & $\mathrm{~b}^{*}$ & $\Delta \mathrm{E}$ \\
\hline \multirow{5}{*}{ Kapur } & Untreated & $24.70 \pm 0.15^{\mathrm{aC}}$ & $1.42 \pm 0.12^{\mathrm{cA}}$ & $1.73 \pm 0.03^{\mathrm{dC}}$ & - \\
\hline & HPP2 & $24.62 \pm 0.14^{\mathrm{aC}}$ & $1.45 \pm 0.25^{\mathrm{cA}}$ & $1.99 \pm 0.21^{\mathrm{cdC}}$ & $0.39 \pm 0.10^{\mathrm{cA}}$ \\
\hline & HPP5 & $24.98 \pm 0.40^{\mathrm{aB}}$ & $1.58 \pm 0.07^{\mathrm{cA}}$ & $2.22 \pm 0.16^{\mathrm{cA}}$ & $0.64 \pm 0.29^{\mathrm{cA}}$ \\
\hline & HPH2 & $18.78 \pm 0.14^{\mathrm{bD}}$ & $13.31 \pm 0.03^{\mathrm{aA}}$ & $12.22 \pm 0.08^{\mathrm{aD}}$ & $16.92 \pm 0.00^{\mathrm{aB}}$ \\
\hline & HPH5 & $15.53 \pm 0.05^{\mathrm{cC}}$ & $12.26 \pm 0.09^{\mathrm{bA}}$ & $10.06 \pm 0.08^{\mathrm{bD}}$ & $16.45 \pm 0.04^{\text {bВ }}$ \\
\hline \multirow{5}{*}{$M a d u$} & Untreated & $26.54 \pm 0.05^{\mathrm{aA}}$ & $0.41 \pm 0.08^{\mathrm{bD}}$ & $2.90 \pm 0.07^{\mathrm{cA}}$ & - \\
\hline & HPP2 & $26.58 \pm 0.04^{\mathrm{aA}}$ & $0.41 \pm 0.08^{\mathrm{bC}}$ & $2.76 \pm 0.02^{\mathrm{cdA}}$ & $0.17 \pm 0.02^{\mathrm{bAB}}$ \\
\hline & HPP5 & $26.53 \pm 0.18^{\mathrm{aA}}$ & $0.31 \pm 0.17^{\mathrm{bC}}$ & $2.49 \pm 0.06^{\mathrm{dA}}$ & $0.47 \pm 0.05^{\mathrm{bA}}$ \\
\hline & НРH2 & $24.74 \pm 0.22^{\mathrm{bA}}$ & $7.56 \pm 0.03^{\mathrm{aD}}$ & $17.52 \pm 0.19^{\mathrm{aA}}$ & $16.38 \pm 0.15^{\mathrm{aC}}$ \\
\hline & HPH5 & $21.41 \pm 0.23^{\mathrm{cA}}$ & $7.42 \pm 0.06^{\mathrm{aD}}$ & $17.09 \pm 0.24^{\mathrm{bA}}$ & $16.63 \pm 0.26^{\mathrm{aB}}$ \\
\hline \multirow{5}{*}{ Serai } & Untreated & $24.58 \pm 0.13^{\mathrm{aC}}$ & $1.01 \pm 0.08^{\mathrm{bB}}$ & $1.44 \pm 0.04^{\mathrm{cD}}$ & - \\
\hline & HРP2 & $24.58 \pm 0.14^{\mathrm{aC}}$ & $0.99 \pm 0.06^{\mathrm{bB}}$ & $1.50 \pm 0.03^{\mathrm{cD}}$ & $0.14 \pm 0.04^{\mathrm{bB}}$ \\
\hline & HPP5 & $25.13 \pm 0.59^{\mathrm{aB}}$ & $0.89 \pm 0.03^{\mathrm{bB}}$ & $1.42 \pm 0.25^{\mathrm{cB}}$ & $0.61 \pm 0.57^{\mathrm{bA}}$ \\
\hline & HPH2 & $21.63 \pm 0.33^{\mathrm{bC}}$ & $11.49 \pm 0.04^{\mathrm{aB}}$ & $15.47 \pm 0.19^{\mathrm{aC}}$ & $17.77 \pm 0.19^{\mathrm{aA}}$ \\
\hline & HPH5 & $18.45 \pm 0.16^{\mathrm{cB}}$ & $11.49 \pm 0.10^{\mathrm{aB}}$ & $13.48 \pm 0.10^{\mathrm{bC}}$ & $17.10 \pm 0.10^{\mathrm{aA}}$ \\
\hline \multirow{5}{*}{ Ragnar } & Untreated & $25.43 \pm 0.12^{\mathrm{aB}}$ & $0.71 \pm 0.06^{\mathrm{bC}}$ & $2.34 \pm 0.06^{\mathrm{bB}}$ & - \\
\hline & HPP2 & $25.33 \pm 0.25^{\mathrm{aB}}$ & $0.78 \pm 0.01^{\mathrm{bB}}$ & $2.35 \pm 0.02^{\text {ьв }}$ & $0.20 \pm 0.16 \mathrm{~b}^{\mathrm{AB}}$ \\
\hline & HPP5 & $25.33 \pm 0.18^{\mathrm{aB}}$ & $0.7 \pm 0.04^{\mathrm{bB}}$ & $2.37 \pm 0.17^{\mathrm{bA}}$ & $0.21 \pm 0.08^{\mathrm{bA}}$ \\
\hline & HPH2 & $22.35 \pm 0.14^{\mathrm{bB}}$ & $8.89 \pm 0.18^{\mathrm{aC}}$ & $16.12 \pm 0.29^{\mathrm{aB}}$ & $16.32 \pm 0.31^{\mathrm{aC}}$ \\
\hline & & $21.65 \pm 0.33^{\mathrm{bA}}$ & $8.96 \pm 0.05^{\mathrm{aC}}$ & $15.82 \pm 0.08^{\mathrm{aB}}$ & $16.25 \pm 0.15^{\mathrm{aB}}$ \\
\hline
\end{tabular}

*Each value from the table represents mean \pm standard deviation $(n=3)$. Values with small letter represent significant difference (Tukey's test, $p<0.05$ ) between treatments while capital letter represents significant difference (Tukey's test, $\mathrm{p}<0.05$ ) between red sugarcane varieties. HPP: High Pressure Processing. HPH: High Pressure Homogenisation. HPP2: 2 min High Pressure Processing; HPP5: 5 min High Pressure Processing; HPH2: 2 min High Pressure Homogenisation; HPH5; HPH5: 5 min High Pressure Homogenisation 
changes were visible in the $\mathrm{b}^{*}$ values (Kapur and Madu), the treatment of HPP was shown to give very little effect on the colour changes of sugarcane juices. The value of overall colour changes $(\Delta \mathrm{E})$ for HPP treatments stay very low, which are below 1 for all sugarcane juice variants.

In contrast, HPH treatment showed significant difference $(p>0.05)$ in the values of $L^{*}, a^{*}$ and $b^{*}$ at alltimepoints. $L^{*}$ values were significantly decreased, while $\mathrm{a}^{*}$ and $\mathrm{b}^{*}$ values were significantly increased, indicating HPH caused darker-appearance juice. It is likely that the heat produced from HPH treatment causes the formation of dark pigments resulted from sugars caramelization (Guerrero-Beltran et al. 2011). Maillard reaction and the deterioration of chlorophyll (Bevilacqua et al. 2010). The colour change indicator, $\Delta \mathrm{E}$ showed the lowest change occur at 16.25 , which was significantly higher that HPP treatments. Therefore, HPP treatment is more effectively in maintaining and preserving the original colour of the samples than HPH treatment.

\section{THE EFFECT OF HPP AND HPH ON THE ENZYMATIC AND MICROBIAL QUALITY OF JUICE}

Juice quality could be influenced by residual endogenous enzyme activity. The polyphenol oxidase (PPO) is an oxidizing enzyme that is responsible for the enzymatic browning of juices (Hanan Yassin et al. 2002). The colour changes will affect appearance and organoleptic properties of the juices. Therefore, inactivation of PPO enzyme is important to maintain the quality of juice.

Based on Table 3, Kapur has the highest tendency to undergo browning process due to the high amount of PPO (2.77 $\Delta$ Abs./min), while Madu exhibited the lowest PPO activity $(0.77 \Delta \mathrm{Abs} . / \mathrm{min})$. HPP treatment for $2 \mathrm{~min}$ did not significantly reduce any PPO activity. Only when the HPP treatment was increased from 2 to $5 \mathrm{~min}$, the activity of PPO was significantly lowered. A maximum inactivation of $23.16 \%$ was observed in Serai, while the lowest inactivation was observed in Madu at $14.15 \%$. Enzyme inactivation under high pressure is due to the irreversible structural rearrangement (Patrignani et al. 2009) and usually only a pressure above $700 \mathrm{MPa}$ is required for the full inactivation of PPO (Guerrero-Beltrán et al. 2005). In contrast to HPP treatment, the utilisation of HPH managed to significantly reduce $(\mathrm{p}<0.05)$ PPO activity in all samples at all-time points except for Madu variant. A maximum reduction of $27.20 \%$ (Serai) was observed during $2 \mathrm{~min}$, while the minimum inactivation at $5 \mathrm{~min}$ was at $40.95 \%$ (Madu). Serai had the maximum PPO activity inactivation of $27.20 \%$ treated with HPH treatment for 2 min and $65.81 \%$ for $5 \mathrm{~min}$. It is interesting to note that the initial amount of PPO did not necessarily cause the largest

TABLE 3. The effect of HPP and HPH on total plate count of red sugarcane juice

\begin{tabular}{|c|c|c|c|}
\hline Varieties & Time $(\min )$ & Log colony forming unit $(\log \mathrm{CFU} / \mathrm{mL})$ & PPO Activity ( $\triangle \mathrm{Abs} . / \mathrm{min})$ \\
\hline \multirow[t]{5}{*}{ Kapur } & Untreated & $6.32 \pm 0.35^{\mathrm{aA}}$ & $2.77 \pm 0.1^{\mathrm{aA}}$ \\
\hline & HPP2 & $6.32 \pm 0.32^{\mathrm{aA}}$ & $2.79 \pm 0.19^{\mathrm{aA}}$ \\
\hline & HPP5 & $6.00 \pm 0.33^{\mathrm{aA}}$ & $2.38 \pm 0.08^{\mathrm{bA}}$ \\
\hline & HPH2 & ND & $2.21 \pm 0.11^{\mathrm{bA}}$ \\
\hline & HPH5 & ND & $1.09 \pm 0.09^{\mathrm{cA}}$ \\
\hline \multirow[t]{5}{*}{$M a d u$} & Untreated & $6.30 \pm 0.36^{\mathrm{aA}}$ & $0.77 \pm 0.06^{\mathrm{aC}}$ \\
\hline & HPP2 & $6.31 \pm 0.35^{\mathrm{aA}}$ & $0.79 \pm 0.02^{\mathrm{aD}}$ \\
\hline & HPP5 & $6.02 \pm 0.35^{\mathrm{aA}}$ & $0.64 \pm 0.02^{\mathrm{bC}}$ \\
\hline & HPH2 & ND & $0.74 \pm 0.03^{\mathrm{aB}}$ \\
\hline & HPH5 & ND & $0.46 \pm 0.01^{\mathrm{cB}}$ \\
\hline \multirow[t]{5}{*}{ Serai } & Untreated & $6.34 \pm 0.36^{\mathrm{aA}}$ & $0.91 \pm 0.05^{\mathrm{aBC}}$ \\
\hline & HРP2 & $6.34 \pm 0.38^{\mathrm{aA}}$ & $0.89 \pm 0.04^{\mathrm{aC}}$ \\
\hline & HPP5 & $6.01 \pm 0.34^{\mathrm{aA}}$ & $0.7 \pm 0.05^{\mathrm{bBC}}$ \\
\hline & HPH2 & ND & $0.66 \pm 0.05^{\text {bВ }}$ \\
\hline & HPH5 & ND & $0.31 \pm 0.04^{\mathrm{cC}}$ \\
\hline \multirow[t]{5}{*}{ Ragnar } & Untreated & $6.47 \pm 0.18^{\mathrm{aA}}$ & $0.97 \pm 0.03^{\mathrm{aB}}$ \\
\hline & HPP2 & $6.48 \pm 0.19^{\mathrm{aA}}$ & $1.07 \pm 0.04^{\mathrm{aB}}$ \\
\hline & HPP5 & $6.03 \pm 0.18^{\mathrm{aA}}$ & $0.78 \pm 0.05^{\mathrm{bB}}$ \\
\hline & HPH2 & ND & $0.8 \pm 0.03^{\text {bB }}$ \\
\hline & HPH5 & ND & $0.51 \pm 0.05^{\mathrm{cB}}$ \\
\hline
\end{tabular}

*Each value from the table represents mean \pm standard deviation $(n=2)$. Values with small letter represent significant difference (Tukey's test, $\mathrm{p}<0.05)$ between treatments while capital letter represents significant difference (Tukey's test, $\mathrm{p}<0.05)$ between red sugarcane varieties. ND: not detected, below detection limit $(<1$ log CFU/g). HPP: High Pressure Processing. HPH: High Pressure Homogenisation 
reduction in PPO activity. In fact, Kapur only responded well to the treatment at HPH 5 min despite having the highest initial PPO. Serai has the biggest potential for commercialisation, as this variant responded well to both HPP and HPH treatment.

In contrast to enzyme inactivation, the application of HPP failed to reduce the microbial count of all juice variants at all-time points, as demonstrated in Table 3. Huang et al. (2015) reported that the microbial content in sugarcane juice treated at $200 \mathrm{MPa}$ for 6 min was not able to significantly reduce the microbial load, although higher pressure at $400 \mathrm{MPa}$ was effective. In contrast, the treatment of HPH at all-time points reduce the microbial counts to zero, indicating the effectiveness of HPH in destroying the pathogenic and spoilage microorganisms. Several studies reported the effectiveness of HPH treatment in deactivating pathogenic and spoilage microorganisms in juices, including orange juice (WeltiChanes et al. 2009), apple juice (Mahima et al. 2014), apricot juice (Patrignani et al. 2009), carrot juice (Pathanibul et al. 2009; Patrignani et al. 2009). It is possible that the high kinetic energy coupled the rising of temperature contributed to the higher rate of pathogen deactivation (Patrignani et al. 2009).

\section{CHANGES OF TPC AND ANTIOXIDANT QUALITIES UNDER HPP AND HPH TREATMENTS}

Phenolic compound is secondary metabolites of plants which can establish antioxidant, anti-mutagen, antiinflammatory, and antimicrobial abilities (Gardner et al. 2000). These compounds are the largest group of chemicals found in the plant kingdom. Therefore, most of the antioxidant activity of plants is also largely contributed by phenolic compounds. Antioxidant is generally defined as a compound that can inhibit oxidation and is proven to play a major role in preserving the human health. FRAP utilise the ability of the compound to convert ferric ions to ferrous ions, while the $\mathrm{EC}_{50}$ is the efficiency concentration to reduce $50 \%$ of DPPH radical. Bigger FRAP value indicates higher antioxidant capacity while lower $\mathrm{EC}_{50}$ indicates more aggressive scavenging activity.

Based on Table 4, all variants registered an increase in TPC under HPP treatment at all-time points. In fact, prolonging the HPP treatment for 5 min significantly improved its TPC compared to 2 min treatment. Ragnar displayed the largest increase amongst all variants, with an increase up to $19.90 \%$ at 5 min HPP treatment, followed by Madu (11.68\%), Serai (11.53\%), and Kapur (10.36\%). However, in term of absolute number, Madu exhibited the highest TPC content at $470.21 \mathrm{mg} \mathrm{GAE} / \mathrm{mL}$ while the lowest is Serai at $366.88 \mathrm{mg} \mathrm{GAE} / \mathrm{mL}$. Therefore, while Madu did not registered the highest increase after HPP treatment, its high TPC content showed its potential to be a marketable commercialised drink.

In contrast, HPH treatment showed significantly lower $(\mathrm{p}<0.05)$ TPC in all samples at all-time points, with largest decline was showed by Madu at $13.76 \%$ while Kapur was the lowest at $7.05 \%$. In spite of the largest decline, Madu still possessed the highest TPC at $363.13 \mathrm{mg} \mathrm{GAE} / \mathrm{mL}$ after $5 \mathrm{~min}$ of HPH. The lowest decline in TPC was shown by Kapur at $7.05 \%$, followed by Serai $(8.48 \%$ ) and Ragnar $(10.70 \%)$. These results indicated that Kapur is the most resistant sugarcane variant as both HPP and HPH treatment produced small changes in its TPC content. Nevertheless, due to its low initial and final amount of TPC content, Kapur is probably not the variant that is suitable for commercialisation.

As antioxidant properties are often linked to TPC, any changes in TPC would usually incur changes in antioxidant activities as well. Based on Figures 1 and 2, the FRAP activity and DPPH of red sugarcane juice were found to be directly proportional to the TPC. Madu demonstrated the highest initial and final antioxidant capacity, while Serai is the lowest, as indicated by TPC, FRAP, and DPPH assay. In proportion with TPC, all variants registered an increase in antioxidant activity under 5 min of HPP treatment, with Ragnar showed the biggest increase in FRAP (27.90\%) and DPPH (37.28\%) activity, followed by Madu variant ( $25.32 \%$ for FRAP and $32.82 \%$ for DPPH). Similarly, HPH treatment caused reduction in antioxidant activity across all variants of sugarcane. In particular, DPPH activity was more negatively affected (ranging from $8.19 \%$ to $45.16 \%$ ) than FRAP activity $(5.25 \%-22.93 \%)$ due to its larger percentage of reduction. Although Madu's DPPH activity diminished significantly (-45\%) under HPH treatments, its FRAP activity was less affected (-8.5\%) and this variant

TABLE 4. The effect of HPP and HPH on total phenolic content (TPC) of red sugarcane juice

\begin{tabular}{cccccc}
\hline \multirow{2}{*}{ Parameters } & \multicolumn{5}{c}{ Total phenolic content (mg GAE/mL) } \\
\cline { 2 - 6 } & Untreated & HPP2 & HPP5 & HPH2 & HPH5 \\
\hline Kapur & $390.21 \pm 1.91^{\mathrm{bB}}$ & $392.71 \pm 7.32^{\mathrm{bB}}$ & $430.63 \pm 6.25^{\mathrm{aB}}$ & $380.63 \pm 2.50^{\mathrm{bB}}$ & $362.71 \pm 2.60^{\mathrm{cA}}$ \\
Madu & $421.05 \pm 4.02^{\mathrm{cA}}$ & $431.88 \pm 2.50^{\mathrm{bA}}$ & $470.21 \pm 2.60^{\mathrm{aA}}$ & $391.05 \pm 2.60^{\mathrm{dA}}$ & $363.13 \pm 2.50^{\mathrm{eA}}$ \\
Serai & $328.96 \pm 1.44^{\mathrm{cD}}$ & $349.38 \pm 3.31^{\mathrm{bD}}$ & $366.88 \pm 2.17^{\mathrm{aC}}$ & $321.88 \pm 5.73^{\mathrm{cD}}$ & $301.05 \pm 3.15^{\mathrm{dC}}$ \\
Ragnar & $358.13 \pm 1.25^{\mathrm{bC}}$ & $362.30 \pm 1.91^{\mathrm{bC}}$ & $429.38 \pm 5.73^{\mathrm{aB}}$ & $346.46 \pm 0.72^{\mathrm{cC}}$ & $319.80 \pm 1.91^{\mathrm{dB}}$ \\
\hline
\end{tabular}

*Each value from the table represents mean \pm standard deviation $(n=3)$. Values with small letter represent significant difference (Tukey’s test, $p<0.05$ ) between treatments while capital letter represents significant difference (Tukey's test, $\mathrm{p}<0.05$ ) between red sugarcane varieties. HPP: High Pressure Processing. HPH: High Pressure Homogenisation. HPP2: 2 min High Pressure Processing; HPP5: 5 min High Pressure Processing; HPH2: 2 min High Pressure Homogenisation; HPH5; HPH5: 5 min High Pressure Homogenisation 
still possessed the highest antioxidant activity for both DPPH and FRAP. As also observed in TPC, Kapur showed the lowest reduction in antioxidant capacity, as only $8.19 \%$ and $5.25 \%$ of FRAP and DPPH were reduced, respectively.

The increase of TPC and antioxidant activity of HPP treatment is probably due to the role of pressure based on Le Chatelier's principle (Varela-Santos et al. 2012). The pressurized cells will also lead to increase in permeability, which allow more polyphenol compounds to permeate out from the cell (Xi et al. 2009). Furthermore, increasing pressure by HPP could cause accelerated destruction of plant cells and tissues which would increase its extraction yield (Huang et al. 2013). In contrast, the reduction of TPC and antioxidant activity in sugarcane juice by HPH is likely not caused by the direct action of HPH itself, but due to the increase in temperature due to the higher kinetic energy. Patrignani et al. (2009) observed similar outcome, as HPH treatment higher than $200 \mathrm{MPa}$ may increase the temperature and lead to the loss in TPC of the juice. However, Suárez-Jacob et al. (2011) demonstrated contradicting finding when they reported that total polyphenolic concentrations of apple juices were not

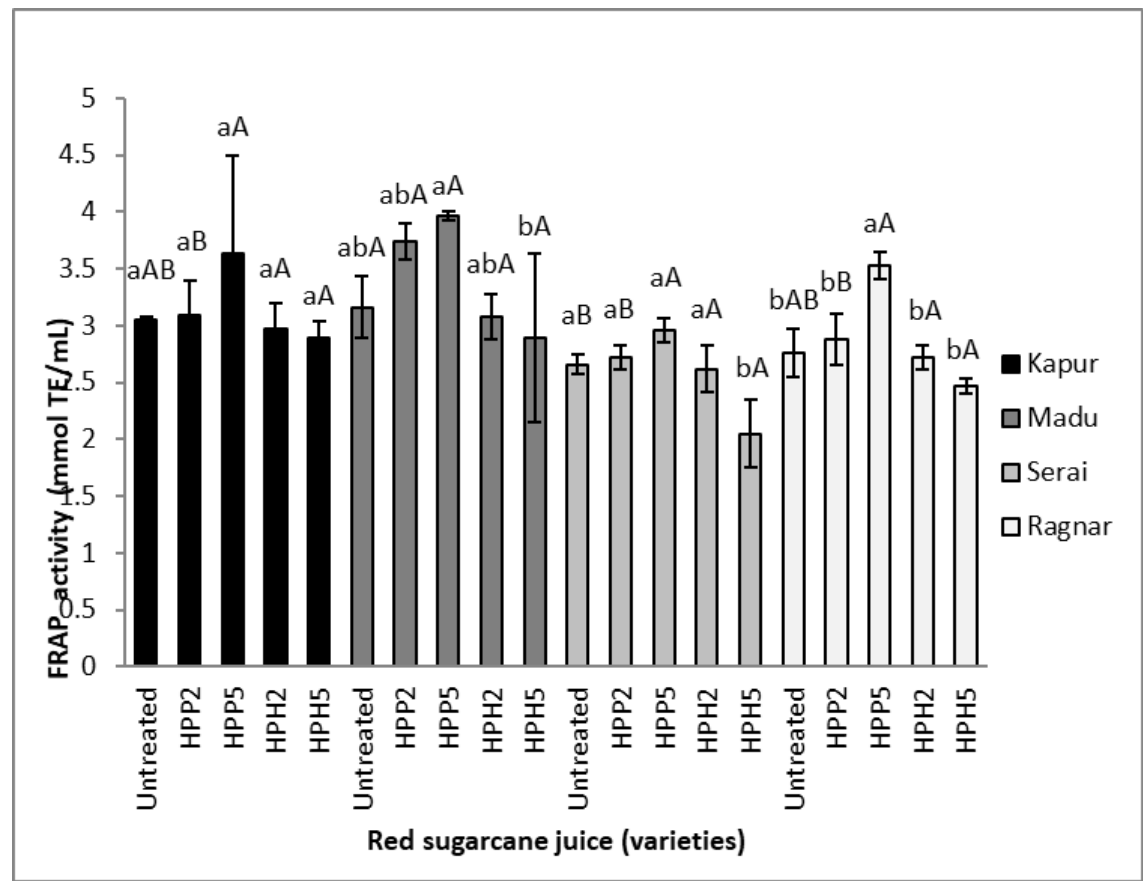

FIGURE 1. The effect of HPP and HPH on the FRAP of red sugarcane juice

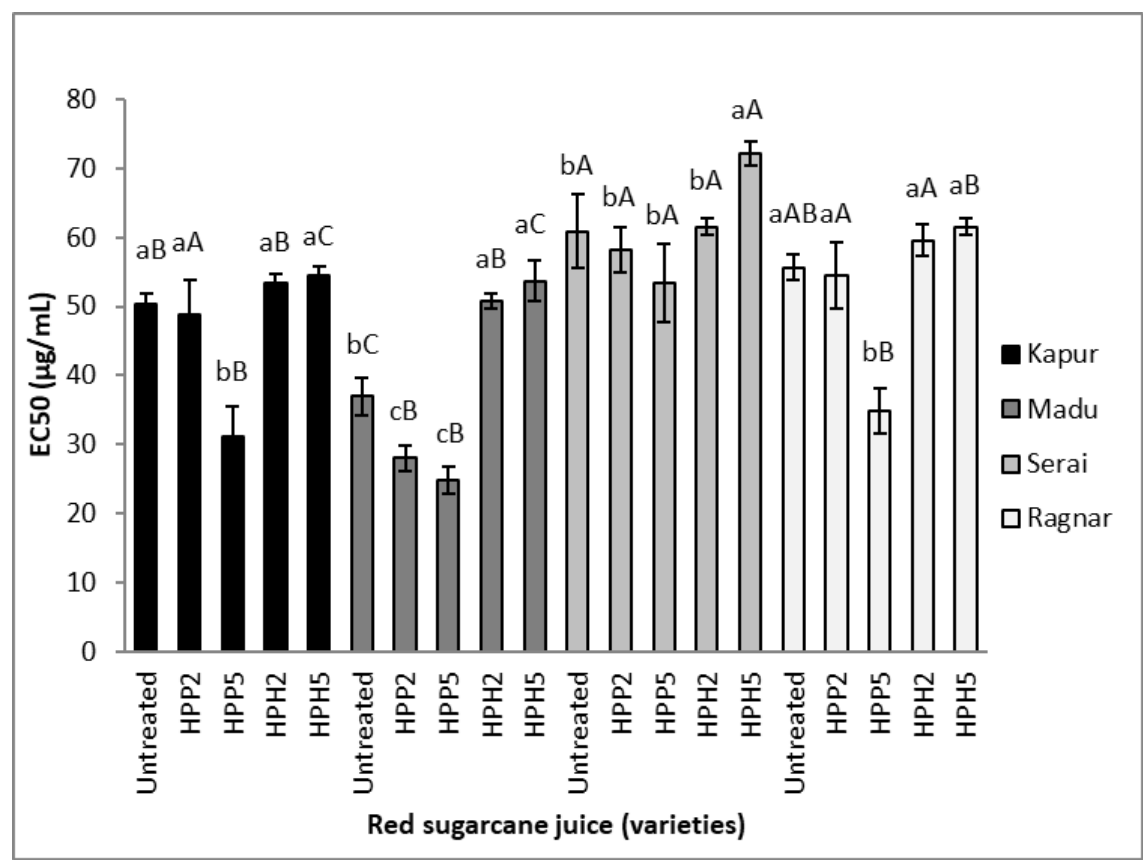

FIGURE 2. The effect of HPP and HPH on the EC50 value of red sugarcane juice 
affected, which is likely due to the application of one spiral type heat-exchanger to minimise heat generation. Overall, these results demonstrated the TPC and antioxidant prowess of Madu variant, but this trait is easily degraded under unsuitable treatments such as HPH.

Each value from the table represents mean \pm standard deviation $(n=3)$. Values with small letter represent significant difference (Tukey's test, $\mathrm{p}<0.05$ ) between treatments while capital letter represents significant difference (Tukey's test, $\mathrm{p}<0.05$ ) across all red sugarcane varieties. HPP: High Pressure Processing. HPH: High Pressure Homogenisation. HPP2: 2 min High Pressure Processing; HPP5: 5 min High Pressure Processing; HPH2: 2 min High Pressure Homogenisation; HPH5; HPH5: 5 min High Pressure Homogenisation.

\section{CONCLUSION}

The red sugarcane juices of different varieties were varied in TSS, $\mathrm{pH}$, colour, total phenolic contents, antioxidant properties and PPO activities before and after different treatments. Madu showed the highest total phenolic content and antioxidant properties amongst variants. All the red sugarcane varieties showed similar respond after the treatments. This study showed that HPP treatment appears to be an effective approach to increase the quantity of antioxidant and retain physicochemical properties (TSS, $\mathrm{pH}$, and colour). In contrast, HPH treatment caused undesirable changes in physicochemical properties. However, HPP treatment showed minimal effect on PPO activity inhibition, which may accelerate the browning process during storage, unlike HPH treatment that showed significant reduction of PPO activity at $5 \mathrm{~min}$. In terms of microbial stability, HPH treatment was found to effectively killed spoilage microorganism compared to HPP treatment due to heat produced during treatment. Therefore, HPH treatment appears to be an effective approach to extend the shelf life of sugarcane juice.

\section{ACKNOWLEDGEMENTS}

This research was conducted under the UPM Putra Grant funding (IPM number 9595700). Author would like to thank all the staff members of Faculty of Food Science and Technology, Universiti Putra Malaysia that have participated in this research work.

\section{REFERENCES}

Benzie, I.F.F. \& Strain, J.J. 1999. Ferric reducing/antioxidant power assay: Direct measure of total antioxidant activity of biological fluids and modified version for simultaneous measurement of total antioxidant power and ascorbic acid concentration. Oxid. Antioxidants Part A, Academic Press 299: 15-27.

Bevilacqua, A., Campaniello, D. \& Sinigaglia, M. 2010. Use of high pressure processing for food preservation. Appl. Altern. Food-Preservation Technol. to Enhanc. Food Saf. Stab. 114-142.
Chen, J.C.P. \& Chou, C.C. 1993. Cane Sugar Handbook: A Manual for Cane Sugar Manufacturers and Their Chemists. 12th ed. John Wiley \& Sons.

Gardner, P.T., White, T.A.C., McPhail, D.B. \& Duthie, G.G. 2000. The relative contributions of vitamin C, carotenoids and phenolics to the antioxidant potential of fruit juices. Food Chem. 68: 471-474.

Guerrero-Beltran, J., Barbosa-Cánovas, G. \& Welti-Chanes, J. 2011. High hydrostatic pressure effect on natural microflora, Saccharomyces cerevisiae, Escherichia coli, and Listeria Innocua in navel orange juice. International Journal of Food Engineering 7(1): doi:10.2202/1556-3758.2166.

Guerrero-Beltrán, J.A., Barbosa-Cánovas, G.V. \& Swanson, B.G. 2005. High hydrostatic pressure processing of fruit and vegetable products. Food Rev. Int. 21: 411-425.

Hajar, A., Raudah, S. \& Muhamad Hafiz, A.R. 2018. The effect of heat treatment and sonication on physicochemical and colour attributes of yellow sugarcane juice. Malaysian Appl. Biol. 47: 129-134.

Hanan Yassin M. Qudsieh, Salmah Yusof, Azizah Osman \& Russly Abdul Rahman. 2002. Effect of maturity on chlorophyll, tannin, color, and polyphenol oxidase (PPO) activity of sugarcane juice (Saccharum officinarum var. yellow cane). J. Agric. Food Chem. 50(6): 1615-1618.

Huang, H.W., Chang, Y.H. \& Wang, C.Y. 2015. High pressure pasteurization of sugarcane juice: Evaluation of microbiological shelf life and quality evolution during refrigerated Storage, Food Bioprocess Technol. 8: 24832494.

Huang, H.W., Hsu, C.P., Yang, B.B. \& Wang, C.Y. 2013. Advances in the extraction of natural ingredients by high pressure extraction technology. Trends Food Sci. Technol. 33: $54-62$.

Kadam, U.S., Ghosh, S.B., De, S., Suprasanna, P., Devasagayam, T.P.A. \& Bapat, V.A. 2008. Antioxidant activity in sugarcane juice and its protective role against radiation induced DNA damage. Food Chem. 106: 1154-1160.

Mahima, A., Rahal, A., Prakash, A.K., Verma, V. \& Kumar, R.D. 2014. Proximate and elemental analyses of Tinospora cordifolia stem. Pakistan J. Biol. Sci. 17: 744-747.

Pathanibul, P., Taylor, T.M., Davidson, P.M. \& Harte, F. 2009. Inactivation of Escherichia coli and Listeria innocua in apple and carrot juices using high pressure homogenisation and nisin. Int. J. Food Microbiol. 129(3): 316-320.

Patrignani, F., Vannini, L., Kamdem, S.L.S., Lanciotti, R. \& Guerzoni, M.E. 2009. Effect of high pressure homogenisation on Saccharomyces cerevisiae inactivation and physico-chemical features in apricot and carrot juices. Int. J. Food Microbiol. 136: 26-31.

Qudsieh, M. \& Yassin, H. 2001. Chemical changes in sugarcane (Saccharum officinarum var. yellow cane) and the extracted juice during development, maturation and postharvest treatments. Food Chem. 75: 131-137.

Siguemoto, É.S. \& Gut, J.A.W. 2017. Validation of spectrophotometric microplate methods for polyphenol oxidase and peroxidase activities analysis in fruits and vegetables. Food Sci. Technol. 37: 148-153.

Sreedevi, P., Rao, P.S. \& Kameswari, P.L. 2017. Effect of high pressure processing on enzyme inactivation and microbial destruction of sugarcane juice. Int. J. Curr. Microbiol. App. Sci. 6: 2000-2006.

Suárez-Jacobo, A., Rüfer, C.E., Gervilla, R., Guamis, B., Roig-Sagués, A.X. \& Saldo, J. 2011. Influence of ultra- 
high pressure homogenisation on antioxidant capacity, polyphenol and vitamin content of clear apple juice. Food Chem. 127: 447-454.

Takara, K., Otsuka, K., Wada, K., Iwasaki, H. \& Yamashita, M. 2007. 1,1-diphenyl-2-picrylhydrazyl radical scavenging activity and tyrosinase inhibitory effects of constituents of sugarcane molasses. Biosci. Biotechnol. Biochem. 71: 183191.

Varela-Santos, E., Ochoa-Martinez, A., Tabilo-Munizaga, G., Reyes, J.E., Pérez-Won, M., Briones-Labarca, V. \& Morales-Castro, J. 2012. Effect of high hydrostatic pressure (HHP) processing on physicochemical properties, bioactive compounds and shelf-life of pomegranate juice. Innov. Food Sci. Emerg. Technol. 13: 13-22.

Vasantha Rupasinghe, H.P. \& Yu, L.J. 2012. Emerging preservation methods for fruit juices and beverages. Food Additive, IntechOpen. DOI: 10.5772/32148. https://www.intechopen.com/books/food-additive/ emerging-preservation-methods-3-for-fruit-juices-andbeverages.

Welti-Chanes, J., Ochoa Velasco, C.E. \& Guerrero-Beltran, J. 2009. High-pressure homogenisation of orange juice to inactivate PME. Innov. Food Sci. Emerg. Technol. 10: 457462.
Xi, J., Shen, D., Zhao, S., Lu, B., Li, Y. \& Zhang, R. 2009. Characterization of polyphenols from green tea leaves using a high hydrostatic pressure extraction. Int. J. Pharm. 382: 139-143.

Yusof, S., Shian, L.S. \& Osman, A. 2000. Changes in quality of sugar-cane juice upon delayed extraction and storage. Food Chem. 68(4): 395-401.

Zhou, C.L., Liu, W., Zhao, J., Yuan, C., Song, Y., Chen, D., Ni, Y.Y. \& Li, Q.H. 2014. The effect of high hydrostatic pressure on the microbiological quality and physicalchemical characteristics of pumpkin (Cucurbita maxima Duch.) during refrigerated storage. Innov. Food Sci. Emerg. Technol. 21: 24-34.

Faculty of Food Science and Technology

Universiti Putra Malaysia

43400, Serdang, Selangor Darul Ehsan

Malaysia

*Corresponding author; email: muhdhafiz@upm.edu.my

Received: 2 May 2019

Accepted: 25 October 2019 
